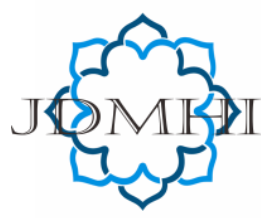

email: jdmhi@walisongo.ac.id

Journal of Digital Marketing and Halal Industry

ISSN: 2716-4810 (print) ISSN: 2716-4802 (online)

\title{
Analysis of the Effect of Visual Merchandising, Store Atmosphere and Sales Promotion on Impulse Buying Behavior
}

\section{Nurudin}

Universitas Islam Negeri Walisongo Semarang, Indonesia

\section{A R T I C LE I N F O}

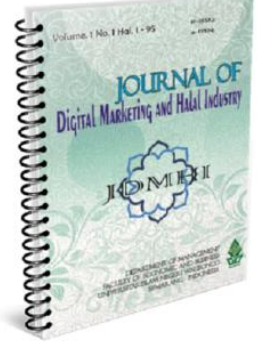

Article history:

Received 24 August 2020

Accepted 19 October 2020

Published 30 October 2020

Keywords:

Visual Merchandising, Store

Atmosphere, Sales Promotion,

Impulse Buying Behavior

\section{A B S T R A C T}

Consumer behavior undergoes a very dynamic and significant development, which is caused by various factors. Consumer behavior is related to the factors behind the interest and decision to buy. This study aims to determine the effect of visual merchandising, store atmosphere, and sales promotion on impulse buying behavior. The method used in this research is quantitative. The sample used is supermarket consumers in Demak. The sampling technique used purposive sampling. The data analysis technique used multiple linear regression. The results showed that visual merchandising had a significant effect on impulsive buying behavior, store atmosphere has a considerable impact on impulsive buying behavior, and sales promotion significantly affected impulsive buying behavior. Therefore, in the future, if you want to optimize buyer interest, these three factors need to be considered.

@2020 Journal of Digital Marketing and Halal Industry

\section{Introduction}

Increasing economic growth has led to increased consumer purchasing power when shopping with a more modern style and more concerned with pleasure and enjoyment. Consumers also often make purchases of goods that are not as needed (Fataron, 2019). This will result in a wasteful nature in finances. In the Al-Quran Surah Al-Isra verses 26-27, which means "...and give to a family close to their rights, to the poor and those who are on the way, and don't be wasteful..." The extravagant is Satan's brother, and in fact, Satan is very suspicious of his god."

With this more modern lifestyle, retailers are competing to offer finished goods and comfortable facilities. In Demak City, there

\footnotetext{
* Corresponding author. email: nurudin@walisongo.ac.id DOI: http://dx.doi.org/10.21580/jdmhi.2020.2.2.6283
} 
are several supermarkets, including Aneka Jaya Demak, Agung Swalayan, and Maharani Swalayan. These supermarkets often offer discounts, ample parking spaces, and friendly employees when serving customers. This is what underlies many consumers in Demak City to make purchases at supermarkets. Selfservice sales turnover is obtained from shopping or purchasing activities made by these consumers. One type of investment made is an unplanned purchase or impulse buying. Impulse buying behavior is a customer purchasing process that tends to be spontaneous and instantaneous without being planned (Engel, 2005: 25). Impulse Buying is defined as "the act of buying that was not previously recognized consciously as a result of a consideration or purchase intention that was formed before entering the store" (Coley, 2003: 65).

According to Jain et al. (2012), impulse buying can be influenced by visual merchandising and merchandise presentation techniques. The visual merchandising display process is often referred to as a "silent salesperson" who provides information through visual media and suggestive selling or suggestions for adding items to consumer purchases (Bhalla \& Anuraag, 2010). Sales promotion is a retailer promotion program to encourage sales or increase sales or maintain customer interest to keep shopping at him (Hendri Ma'ruf, 2005). The store atmosphere is an environmental design through visual communication, lighting, color, music, and fragrances to design emotional responses and customer perceptions and to influence customers in buying goods" (Nofiawaty, 2014).

The research gap in this study is visual merchandising. Saputra (2019) conducted a study that showed that visual merchandising had a positive and significant effect on impulsive buying. However, the results of Jovita Guntara's research differ. The results show that the visible merchandising variable is not significant to impulsive buying. Sari (2015) provides the results of his research that promotion significantly affects impulse buying. The products of Yang's research et al. give the opposite result that advertising does not affect impulse buying. This study aims to determine the effect of visual merchandising, store atmosphere, and sales promotion on impulse buying behavior.

\section{Literature Review}

\section{Impulse Buying}

According to Lisda (2010), impulse buying is the process of purchasing an item where the buyer does not have the intention to buy beforehand. It can be said to buy without a plan or instant purchase. Meanwhile, according to Mowen and Minor (2002), impulse purchase is an act of believing that was not previously recognized consciously due to consideration or purchase intention formed before entering a store. It is clarified by the opinion of Rook and Fisher (1995) that impulsive buying is defined as the tendency of consumers to buy spontaneously, reflexively, suddenly, and automatically. It can be said that impulse buying is something natural and is a quick reaction. Sutisna (2002) explains that impulsive buying occurs when consumers make informed purchasing decisions

suddenly. The urge to make a purchase is so strong that consumers no longer reason for their investment. According to Park (2006), impulsive purchases often appear suddenly, 
spontaneously, and more emotional than rational, are often seen as something wrong than something useful. Consumers tend to feel "out of control" when buying goods automatically impulsive. This is in line with the opinion expressed by Schiffman and Kanuk (2007) that impulsive buying is an emotional or impulsive decision. Emotions can be compelling and serve as the basis of the dominant buying motive.

According to Rook's research, impulsive buying has the following characteristics:

1. Spontaneity (spontaneity). Purchases occur unexpectedly, are unexpected, and motivate consumers to buy now, often seen as a response to visual stimulation taking place at the point of sale.

2. Strength, compulsion, and intensity, to put things aside and take immediate action.

3. Excitement and stimulation.

4. Motivation to buy that comes suddenly, accompanied by feelings of pleasure and out of control.

5. Disregard for the consequences. The urge to buy can be so hard to resist that the adverse effects are ignored.

According to Loudon and Bita (in Fikrah Wathani, 2009), five crucial elements distinguish impulsive and non-impulsive consumer behavior. These elements are:

1. The consumer feels a sudden and spontaneous urge to take action different from the previous behavior.

2. The sudden urge to make a purchase

3. puts consumers in a state of psychological imbalance, where they feel temporarily out of control.
4. Consumers will experience psychological conflicts and a balance between immediate need satisfaction and the long-term consequences of the purchase.

5. Consumers will reduce cognitive evaluation (thought processes) of certain products.

6. Consumers often do impulse buying without pay attention to the consequences in the future.

Loudon and Bitta (in Tania Varerina, 2010) suggest four types of impulsive buying. The four types of impulsive buying are as follows:

1. Pure impulse

Purchases were made purely without plans or impressions sudden. Usually, consumers buy without consideration or do not believe in the usual pattern. This happens after consumers see the goods on display at the store or other place of purchase so that the desire to have it immediately arises.

2. Suggestion impulse

Purchases are made without a plan when shopping at a shopping center. This purchase occurs when consumers see a product or see how to use it. Also, buyers are influenced because they are convinced by the sellers they meet while shopping and finally decide to purchase.

3. Impulse reminder

Purchases occur when consumers suddenly think to make purchases of products out of ordinary assets. This happens after consumers see an advertisement or brochure in a shopping place.

4. Planned impulse 
Purchases are made because they have been planned. Consumers enter the store with the expectation and intention to make purchases based on special prices, coupons, and preferences. However, when the item in question does not match what you want, the purchase is made by buying the same type of goods but with a different brand or size.

\section{Visual Merchandising}

Visual merchandising is a salesperson who does not speak but can definitively convey sales messages through visual stimulation. Visual merchandising is a technique in presenting an attractive appearance to potential customers. Visual merchandising can focus on supporting colors and accessories. Merchandising is part of the retail mix. A company procures products following the business that the store provides in the appropriate amount, time, and price to achieve the target store or retail company (Hendri, 2005). Merchandising is products that retailers sell to consumers in their outlets, while merchandising can be interpreted as an effort to procure and handle goods (Sujana, 2005). This is supported by Mehta \& Chugan (2013) 's research, which suggests that visual merchandising is the only technique to create euphoria in the clothing industry through presentations displayed in stores.

\section{Store Atmosphere}

The atmosphere (shop atmosphere) is a planned atmosphere according to the target market and can attract consumers to buy (Kotler 2005). The store atmosphere affects the emotional state of the buyer that causes or influences a purchase. The emotional state will create two dominant feelings, namely feeling happy and arousing desire. Along with an increasingly competitive market, market players are required to be smart in offering other things, not only always at a discount, but also the experience of buying a product. The use of the right atmosphere store will create an aesthetic impression and help improve the shop / retail image in the customer's perception, encouraging excellent buying interest. An in-depth definition is explained by Berman and Evans (2010). They define it as follows: "atmosphere refers to the store's physical characteristics used to develop an image and draw customers. From the above definition, it can be concluded that it is essential for a store to highlight its physical appearance. The shop's atmosphere is useful for building an image and attracting customer interest.

The many definitions and descriptions above show the benefits of structuring a shop's environment concerning building the visitors' impression and comfort. A comfortable shop environment will eventually become flexible as a medium to make a store's image. Also, the store atmosphere's arrangement can help direct consumers' attention in driving consumer reactions and emotions. According to Levi and Weitz (2009), the shop atmosphere consists of two things, namely Instore atmosphere and Out store atmosphere a. In-Store Atmosphere Instore atmosphere is an indoor setting that concerns:

1. Internal layout

It arranges various indoor facilities consisting of the table and chairs 
layout, the cashier table layout, the lighting layout, and good layout and air conditioning.

2. Sound is the entire sound presented in the room to create a relaxed impression consisting of live music served by the restaurant and music from the sound system.

3. The smell is aromas presented in the room to create an appetite that arises from the aroma of food and smells and perfume caused by room deodorizers.

4. The texture is a physical appearance such as tables and chairs, as well as accessories and rooms.

5. Interior design is the arrangement of spaces in the restaurant. The suitability includes the visitor's room's usefulness with the road that provides comfort, bar counter design, table arrangement, the arrangement of paintings, and an indoor lighting system.

\section{Sales promotion}

sales promotion is a form of direct persuasion through various incentives that can be arranged to stimulate product purchases immediately and increase the number of goods purchased by customers (Tjiptono, 2008). Meanwhile, according to Cummins (2010), sales promotion is a series of techniques used to achieve sales/marketing goals with costeffective use by providing added value to products or services both to intermediaries and direct users, usually not limited to a specific period. According to Kotler and Keller (2009), sales promotion is a core ingredient in a marketing campaign, consisting of a collection of incentive tools, mostly short- term, designed to stimulate faster or larger purchases of specific products or services by consumers or trading. According to Kotler and Armstrong (2001), the purpose of sales promotion is to attract consumers to try new products, luring consumers to leave competitors' products. Loyal customers. In essence, advertising is a form of marketing communication. What is meant by marketing communication is a marketing activity that seeks to spread information, influence, and remind the company's target market and its products to be willing to accept, buy, and be loyal to the products offered by the company concerned Nurudin (2018).

\section{The Method, Data, and Analysis}

The type of data used by the author in this study is a quantitative approach. As a research method based on positivism, the quantitative system examines specific populations or data collection samples using research instruments. Data analysis is quantitative/statistical to test predetermined hypotheses. Meanwhile, the data source used by the author is primary data. Primary Data is directly obtained from the first source, both from individuals, such as interviews or the results of filling out questionnaires. Preliminary data in this study were obtained from the effects of filling out a questionnaire that was distributed directly to consumers who shop at Demak supermarkets.

\section{Result and Discussion}

Table 1. R-Table

\begin{tabular}{llllll}
\hline No & Variable & Indicator & r count & r table & $\begin{array}{c}\text { Descri } \\
\text { ption }\end{array}$ \\
\hline \multirow{4}{*}{1} & Impulse & P1 & 0,715 & 0,361 & Valid \\
& Buying & P2 & 0,582 & 0,361 & Valid \\
& Behavior & P3 & 0,666 & 0,361 & Valid \\
& & P4 & 0,538 & 0,361 & Valid
\end{tabular}




\begin{tabular}{|c|c|c|c|c|c|}
\hline & \multirow{8}{*}{$\begin{array}{l}\text { visual } \\
\text { merchan } \\
\text { dising }\end{array}$} & P5 & 1,343 & 0,361 & Valid \\
\hline \multirow{6}{*}{2} & & P6 & 0,672 & 0,361 & Valid \\
\hline & & P1 & 0,800 & 0,361 & Valid \\
\hline & & P2 & 0,565 & 0,361 & Valid \\
\hline & & P3 & 0,872 & 0,361 & Valid \\
\hline & & P4 & 0,795 & 0,361 & Valid \\
\hline & & P5 & 0,862 & 0,361 & Valid \\
\hline & & P6 & 0,886 & 0,361 & Valid \\
\hline & & P1 & 0,382 & 0,361 & Valid \\
\hline \multirow{4}{*}{3} & Store & P2 & 0,378 & 0,361 & Valid \\
\hline & Atmosph & P3 & 0,432 & 0,361 & Valid \\
\hline & ere & P4 & 1,155 & 0,361 & Valid \\
\hline & & P5 & 0,898 & 0,361 & Valid \\
\hline \multirow[t]{4}{*}{4} & Sales & P1 & 0,492 & 0,361 & Valid \\
\hline & Promotio & P2 & 0,528 & 0,361 & Valid \\
\hline & $\mathrm{n}$ & P3 & 0,632 & 0,361 & Valid \\
\hline & & P4 & 0,655 & 0,361 & Valid \\
\hline
\end{tabular}

Based on Table 1, it is known that the calculated $r$-value for each indicator is $>r$ table, so it can be concluded that the data used in this study is valid.

Table 2. Reliability Test Results

\begin{tabular}{llll}
\hline No & Variabel & r11 & rtabel \\
\hline 1 & Impulse $\quad$ Buying & 1,007 & 0,361 \\
& Behavior & & \\
2 & visual merchandising & 0,865 & 0,361 \\
3 & Store Atmosphere & 1,027 & 0,361 \\
4 & Sales Promotion & 0,906 & 0,361 \\
\hline
\end{tabular}

Of the reliability test presented in Table 2, each research variable has an $\mathrm{r} 11$ of more than 0.361, so it can be concluded that all research variables are reliable.

Table 3. Kolmogorov Smirnov Normality Test

\begin{tabular}{|c|c|c|}
\hline \multicolumn{3}{|c|}{ One-Sample Kolmogorov-Smirnov Test } \\
\hline & & Unstandardized \\
\hline & & Residual \\
\hline $\mathrm{N}$ & & 92 \\
\hline \multirow[t]{2}{*}{ Normal Parameters ${ }^{\mathrm{a}, \mathrm{b}}$} & Mean & .0000000 \\
\hline & $\begin{array}{l}\text { Std. } \\
\text { Deviation }\end{array}$ & .92900358 \\
\hline Extreme & Absolute & .089 \\
\hline
\end{tabular}
Differences
Positive $\quad .089$
Asymp. Sig. (2-tailed)
Negative $\quad-.070$
.089
$.066^{\mathrm{C}}$
a. Test distribution is Normal.
b. Calculated from data.
c. Lilliefors Significance Correction.

Based on the Kolmogorov Smirnov normality test results, it is known that the significance value is $0.066>0.05$, so it can be concluded that the residual value is normally distributed.

Tabel 4. Uji Multikolinieritas

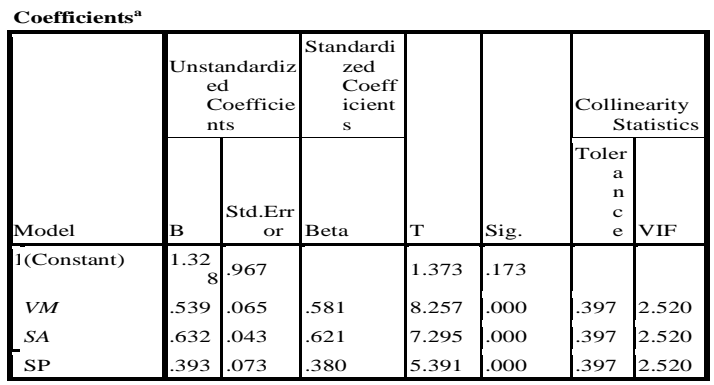

From the test results through the Variance Inflation Factor (VIF), the output results above, variable VM (visual merchandising), SA (store atmosphere), and SP (sales promotion), has a VIF of not more than ten and a tolerance value of not less than 0.1 . It can be concluded that the multiple regression model is free from multicollinearity.

Table 5. Heteroscedasticity Glacier Test Coefficients $^{\mathrm{a}}$

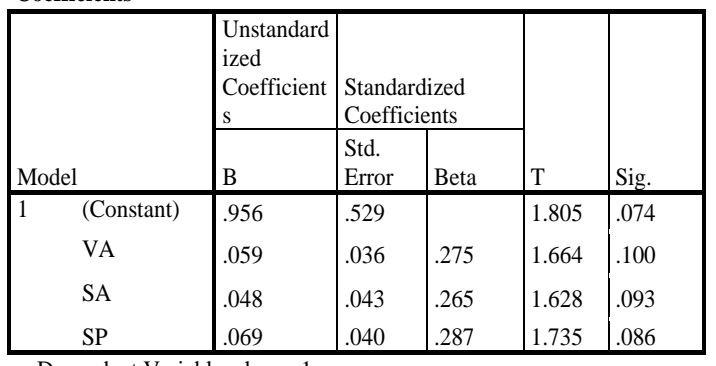

a. Dependent Variable: abs-res1 
for the visual merchandising variable was $0.100>0.05$. Store atmosphere variable is $0.093>0.05$, and sales promotion variable is 0.086> 0.05. Thus, free from heteroscedasticity.

Table 6. Linear Regression Test Results

\begin{tabular}{|c|c|c|c|c|c|}
\hline \multirow[b]{2}{*}{ Model } & \multicolumn{5}{|c|}{$\begin{array}{c}\text { Standardiz } \\
\text { ed } \\
\text { Coeffi } \\
\text { cients }\end{array}$} \\
\hline & B & Std. Error & Beta & $\mathrm{T}$ & Sig. \\
\hline 1 (Constant) & 1.328 & .967 & & 1.373 & .173 \\
\hline VM & .539 & .065 & .581 & 8.257 & .000 \\
\hline SA & .632 & .043 & .621 & 7.295 & .004 \\
\hline SP & .393 & .073 & .380 & 5.391 & .000 \\
\hline
\end{tabular}

Dependent variable: impulse buying behavior

From the table above, it can be seen that the results of multiple regression analysis for visual merchandising variables are 0.539 , store atmosphere variable is 0.632 , and sales promotion is 0.393 . So that the regression equation model obtained is:

$\mathrm{Y}=\mathrm{a}+\mathrm{b} 1 \mathrm{X} 1+\mathrm{b} 2 \mathrm{X} 2+\mathrm{b} 3 \mathrm{X} 3+\mathrm{e}$.

$\mathrm{Y}=1.328+0.539 \mathrm{X} 1+0.632+0.393 \mathrm{X} 3+\mathrm{e}$

Beta value in the unstandardized coefficient. Interpretation of the Research Equation:

1. The constant value $\mathrm{a}=1.328$, meaning that if the variables visual merchandising, store atmosphere, and sales promotion are not included in the study, the variable impulse buying behavior of consumers still tends to increase by $1.328 \%$

2. The coefficient $\mathrm{X} 1=0.539$, meaning that if the visual merchandising variable is raised again, assuming the shop's goods are complete, price suitability, merchandise management, and goods feasibility. Then the variable impulse buying consumer behavior will increase by $53.9 \%$. Assuming other variables are considered constant.

3. The coefficient of $\mathrm{X} 2=0.632$ means that if the store atmosphere variable is increased, the assumption of interior space arrangement, facilities, aroma, exterior, and doors is assumed. The consumer impulsive buying behavior variable will increase by $63.2 \%$, assuming other variables are considered constant.

4. The coefficient of $\mathrm{X} 3=0.393$, meaning that if the sales promotion variable is increased again, with the assumption of interior space arrangement, the arrangement of various facilities, aroma, an array of exterior space. Then the variable impulse buying consumer behavior will increase by $39.3 \%$. Assuming other independent variables are considered constant.

Table 7. Coefficient of Determination

\begin{tabular}{|c|c|c|c|c|}
\hline \multicolumn{5}{|c|}{ Model Summary $^{\text {b }}$} \\
\hline Model & $\mathrm{R}$ & $\begin{array}{l}\mathrm{R} \\
\text { Square }\end{array}$ & $\begin{array}{l}\text { Adjust Std. Error } \\
\text { ed R of the } \\
\text { Square Estimate }\end{array}$ & $\begin{array}{l}\text { Durbin- } \\
\text { Watson }\end{array}$ \\
\hline 1 & $.908^{\mathrm{a}}$ & .825 & $.821 \quad .93938$ & 1.730 \\
\hline \multicolumn{5}{|c|}{ a. Predictors: (Constant), VM, SA, SP } \\
\hline
\end{tabular}

Data from SPSS 23.00 shows that the results of the above determination have an adjusted coefficient of determination of $82.5 \%$, which means that in addition to the independent 
variables (visual merchandising, store atmosphere, and sales promotion), there are still other independent variables that affect the impulse buying behavior of $17,5 \%$.

Table $8 . \mathrm{F}$ test (Anova)

ANOVAa

\begin{tabular}{|c|c|c|c|c|c|}
\hline Model & & $\begin{array}{l}\text { Sum of } \\
\text { Squares Df }\end{array}$ & $\begin{array}{l}\text { Mean } \\
\text { Square }\end{array}$ & F & Sig. \\
\hline \multirow[t]{3}{*}{1} & Regression & 369.9302 & 184.965 & 209.606 & $.000 \mathrm{a}$ \\
\hline & Residual & $\begin{array}{ll}78.537 \quad 89\end{array}$ & .882 & & \\
\hline & Total & 448.46791 & & & \\
\hline
\end{tabular}

a. Dependent Variable: impulse buying behavior

b. Predictors: (Constant), VM, SA, SP

The ANOVA test or F-test shows that the $\mathrm{F}$ analysis results are 189,562 with a probability level of 0,000 (significant). The probability value $<0.05$, so from the data above, it can be concluded that the variable X1 (visual merchandising), variable $\mathrm{X} 2$ (store atmosphere), and variable X3 (sales promotion) together have a positive effect on variable Y (impulse buying behavior).

\section{Table 9. T-test}

Dependent variable: impulse buying behavior

From the Coefficient table analysis above, it shows that the effect of the independent variable partially on the dependent variable is as follows:

a. The visual merchandising variable has a significant value below 0.05 . Therefore, visual merchandising partially affects impulse buying behavior.

b. Store atmosphere variable has a significant value below 0.05 . Therefore, store atmosphere partially affects the impulse buying behavior. c. The sales promotion variable has a significant value below 0.05 , therefore sales promotion partially affects the impulse buying behavior.

\section{Discussion}

Each of the independent variables is visual merchandising, store atmosphere, and sales promotion, and the dependent variable is impulsive buying behavior. The test results show that visual merchandising, store atmosphere, and sales promotion significantly affect impulse buying behavior. Based on the instrument's validity and reliability, the $r$ count for each item> $\mathrm{r}$ table is 0.172 .

Based on these results, each item in the research questionnaire was declared valid. Thus, obtained significant influences on the calculation of the effect of other variables. As for the multiple linear regression coefficients in this study, it is known that the regression coefficient for the independent Variable visual merchandising $(\mathrm{X} 1)$ is 0.539 , the store atmosphere (X2) is 0.632, and the sales

Coefficients $^{\mathbf{a}}$

\begin{tabular}{llllll}
\hline \multicolumn{5}{c}{$\begin{array}{l}\text { Unstandardized } \\
\text { Coefficients }\end{array}$} & $\begin{array}{l}\text { dardized } \\
\text { Coefficien } \\
\text { ts }\end{array}$ \\
Model & B & Std. Error & Beta & T & Sig. \\
\hline 1(Constant) & 1.328 & .967 & & 1.373 & .173 \\
VM & .539 & .065 & .581 & 8.257 & .000 \\
SA & .632 & .043 & .621 & 7.295 & .004 \\
SP & .393 & .073 & .380 & 5.391 & .000 \\
\hline
\end{tabular}

promotion (X3) is 0.393 with a constant of 1.328 so that the regression equation will be obtained as follows: $\mathrm{Y}=1.328+0.539 \mathrm{X} 1+$ $0.632 \mathrm{X} 2+0.393 \mathrm{X} 3+\mathrm{e}$.

The beta value in the Unstandardized Coefficient of the visual merchandising 
Variable is 0.539 , meaning that if the visible merchandising variable is increased by one unit, it will increase by $53.9 \%$. The beta value in the Unstandardized Coefficient variable store atmosphere is 0.632 , meaning that if the store atmosphere variable is increased by one unit, it will increase by $63.2 \%$. The beta value in the Unstandardized Coefficient of the sales promotion variable is 0.393 , meaning that if the sales promotion variable is increased by one unit, it will increase by $39.3 \%$.

Furthermore, to find out how much the contribution of the independent variables (visual merchandising, store atmosphere and sales promotion) to the dependent variable (impulse buying) behavior) can be seen in the coefficient of determination processed with SPSS version 23.00, the result of the above determination is 0.825 or $82.5 \%$, which means that in addition to the independent variables (visual merchandising, store atmosphere, and sales promotion) there are still other independent variables that affect impulse buying. Submitted in the study is accepted. This means that sales promotion significantly affects impulse buying behavior. The regression coefficient of the regression coefficient is 0.393 , which means that the sales promotion variable's regression coefficient is significant to the impulse buying behavior. If the store atmosphere variable, regression coefficient increases by 0.393 and increases by one unit, it will increase by $39.3 \%$ with a constant value of 1.328 . Therefore, sales promotion partially has a significant effect on supermarket consumers' impulse buying behavior in Demak.

\section{Conclusion}

Based on data analysis and discussion of research results, it can be concluded that the visual merchandising variable has a positive and significant effect on the impulse buying behavior of self-service consumers in Demak. Store atmosphere variable has a positive and significant impact on supermarket consumers' impulse buying behavior in Demak. The sales promotion variable has a positive and significant effect on supermarket consumers' impulse buying behavior in Demak.

\section{References}

Baroroh, Ali. (2008). Trik-trik Anlisis Statistik dengan SPSS 15. Jakarta:Alex Media Mumputindo.

Bell, J. \& Ternus, K. (2012). Silent Selling 4th Ed. New York: Fairchild Publications

Berman dan Evans, (2010). "Retail Management". 12th Edition. Jakarta; Pearson

Bhalla, S. \& Anuraag, S. (2010). Visual Merchandising. New Delhi: Mcgraw Hill.

Coley A., \& Burgess B. (2003). Gender Differences In Cognitive And Affective Impulse Buying. Journal Of Fashion Marketing And Management, 7(3), Pp. 282-295.

Cummins, Julian. (2010). Promosi Penjualan. Binarupa Aksara, Tangerang.

Engel, James F, Roger D. Blackwell, Paul W. Miniard, 2005. Consumer Behavior 8th Edition, Orlando: The Dryden Press.

Fataron, Z. A. (2019). Online Impulse Buying Behaviour: Case Study On Users Of 
Tokopedia. Journal of Digital Marketing and Halal Industry, 1(1), 47-60. https://doi.org/10.21580/jdmhi.2019.1. 1.4762

Fitriana, Ana. (2016), Analisis Pengaruh Display Interior Terhadap Perilaku Pembelian Impulsif Konsumen Indomaret Pontianak. Journal Of Applied Intelligent System, Vol. 1, No.2, Juni 2016: $90-102$

Gozali, Imam. (2005). Aplikasi Analisis Multivariate dengan Program SPSS. edisi ketiga. Semarang: Badan Penerbit UNDIP.

Ghozali, Imam. (2016). Aplikasi Analisis Multivariate dengan Program IBM SPSS 23. Semarang: Universitas Dipenogoro.

Guntara, Jovita. (2017) Pengaruh Visual Merchandising Terhadap Impulsive Buying Melalui Posituve Emotion pada Zara Surabaya, Jurnal Manajemen Pemasaran, Vol. 11, No. 1.

Jain, V., Sharma, A., Narwal, P. (2012). Impact Of Visual Merchandising On Consumer Behavior Towards Women's Apparel. International Journal Of Research In Management, 5(2),

Japarianto, E. (2009). Pengaruh Shopping Life Style Dan Fashion Involvement Terhadap Impulse Buying Behavior Masyarakat High Income Surabaya.

Kotler, Philip. (2005). Manajemen Pemasaran. Jilid 1 dan 2. Jakarta : PT Indeks Kelompok Gramedia.

Kotler, Philip Dan Kevin Lane Keller. (2009). Manajemen Pemasaran. Edisi 13 Jilid satu. Erlangga : Jakarta
Kotler, Amstrong. (2001). Prinsip-prinsip pemasaran, Edisi keduabelas, Jilid 1. Jakarta: Erlangga

Kurniawan, Denny, (2013). Pengaruh Promosi Dan Store Atmosphere Terhadap Impulse Buying Dengan Shopping Emotion Sebagai Variabel Intervening Studi Kasus Di Matahari Department Store Cabang Supermall Surabaya, 1(2), $1-8$.

Kwan, Oky Gunawan (2016), Pengaruh Sales Promotion Dan Store Atmosphere Terhadap Impulse Buying Dengan Positive Emotion Sebagai Variabel Intervening Pada Planet Sports Tunjungan Plaza Surabaya. Jurnal Manajemen Pemasaran, Vol. 10, No. 1, April 2016

Levy M. \& Weitz B.A. (2007). Retailing Manajement. 6th Edition. Boston: Mc Graw Hill.

Mehta, N. P. \& Chugan, P. K. (2013). The Impact Of Visual Merchandising On Impulse Buying Behavior Of Consumers: A Case From Central Mall Of Ahmedabad India. Universal Journal Of Management. 1(2): 76-82.

Mowen, Jonh C \& Minor, Michael. (2002). Perilaku Konsumen Jilid 1. Alih Bahasa: Lina Salim. Jakarta: Erlangga.

Nurudin. (2018). Strategi Pemasaran Menggunakan Sales Promotion Girls (Spg) Dalam Perspektif Ekonomi Islam (Studi Kasus Pada PT. Nasmoco Semarang). Jurnal At-Taqaddum Vol. 10 No. 2 
Nofiawaty, B.Y. (2014). Pengaruh Store Atmosphere Terhadap Impulse buying behavior Konsumen Pada Outlet Nyenyes Palembang. Jurnal Manajemen Dan Bisnis Sriwijaya, 12.

Park, Eun Joo., Eun Young Kim., and Judith Cardona Forney. (2006). A Structural Model of Fashion-oriented Impulse Buying Behavior. Journal of Fashion Marketing and Management. Vol. 10 No.4: 433-446.

Rahmasari, Lisda . (2010). Menciptakan Impulse Buying. Majalah Ilmiah Informatika. Vol. 1 No.3. hlm.56-68.

Rook, D.W. \& Fisher, R.J. (1995). Normative Influences on Impulsive Buying. Journal of Consumer Research. Vol.22.hlm. 305-313

Saputra, Yoga Aji. (2019)Pengaruh Visual Merchandising Terhadap ImpulsiveBuying pada Produk Fashion (Studi pada Konsumen Swalayan ADA Semarang), SKRIPSI: UNNES Semarang.

Sari, Taman Ayu, Dewa dan Alit Suryani, 2015. Pengaruh Merchandising, Promosi dan Atmosfir Toko Terhadap Impulse Buying.

Schiffman, L. G. \&Kanuk, Leslie. L. (2007). Consumer Behavior. America: Pearson Prentice Hall

Sudarsono, Jovita Guntara (2017), Pengaruh Visual Merchandising Terhadap Impulse Buying Melalui Positive Emotion Pada Zara Surabaya. Jurnal Manajemen Pemasaran, Vol. 11, No. 1, April 2017

Sugiyono, 2004, Metode Penelitian Bisnis, Cv. Alfabeta, Bandung
Sugiyono. (2011). Metode Penelitian Kuantitatif, Kualitatif Dan R \& D. Bandung: Alfabeta.

Sutisna. (2002). Perilaku Konsumen dan Komunikasi Pemasaran. Bandung: PT Remaja Rosdakarya.

Tjiptono, Fandy. (2008). Strategi Pemasaran. Edisi 3. Yogyakarta: Andi Offset

Utami, C. W. (2010). Manajemen Ritel: Strategi Dan Implementasi Operasional Bisnis Ritel Moderen Di Indonesia. Jakarta: Salemba Empat.

Varerina, Tania. (2010). Perilaku Pembelian Impulsif Produk Pakaian Masyarakat Urban di Kota Jakarta dan Bandung. Tesis. Jakarta: Universitas Indonesia

Wathani, Fikrah. (2009). Perbedaan Kecenderungan Pembelian Impulsif Produk Pakaian Ditinjau dari Peran Gender. Sumatera Utara: Universitas Sumatera Utara.

Wibisono, Dermawan. (2003). Riset Bisnis, Panduan Bagi Praktisi dan Akademisi. Jakarta : Gramedia Pustaka Utama. 